\title{
Transportation Planning Studies for Socio-Economic Development of Depressed Sub-Regions: A Review
}

\author{
MIR AFTAB HUSSAIN TALPUR*, TAUHA HUSSAIN ALI**, IMTIAZ AHMED CHANDIO*, AND \\ FAHAD AHMED SHAIKH*
}

RECEIVED ON 02.08.2017 ACCEPTED ON 12.02.2018

\begin{abstract}
Transport sector can be considered as a backbone of the national and regional economies. Well-arranged transportation facilities are essential for the movement of people and goods, which can make nations agile and strong to face ever-increasing global and local socioeconomic problems. However, most of the developing countries were facing acute transport-related problems, i.e. absence of transport policies, inaccessibility, the proper road network hierarchy and unavailability of low-cost transportation services, especially for rural dwellers. Hence, the aim of this research is to propose policy implications by reviewing suitable literature associated with regional transportation planning, which can be essential to upsurge accessibility standards and abolish the transport-related problems of the rural sub-regions of developing countries. This research article is intended for the planned development and socioeconomic well-being of depressed sub-regions, which are struggling with the problem of transportation inaccessibility over the years. It was found that accessibility is a dominant element of transportation studies in rural subregions, if addressed by the concerned authorities or planning agencies; the deprived sub-regions can flourish and prosper with the passage of time.
\end{abstract}

Key Words: Transport Sector, Socioeconomic Development, Depressed Sub-Regions, Transport Inaccessibility.

\section{INTRODUCTION}

$\mathrm{P}$ lanning is a multi-disciplinary approach $[1,2]$, which is connected with our lives over the years and played a pivotal role in the civilization of mankind [3]. Regional Planning is a tool that can assist in initiating the development process within remote or depressed sub-regions. The depressed sub-regions can be defined as, "the regions having low employment opportunities and labor productivity, migrating population in search of a better life, poor physical and socio-economic infrastructure, declining socio-economic opportunities, low per capita and household incomes, struggling agriculture sector and inaccessible deprived urban or rural population [4]". Inaccessibility can be considered as a main cause, which shattered the ability of the rural population to reach desired destinations on time. Hence, in this situation, transportation sector can inject

Authors E-Mail: (aftab.talpur@faculty.muet.edu.pk, sacharvi2@gmail.com,imtiaz.chandio@faculty.muet.edu.pk, fahad.shaikh@faculty.muet.edu.pk)

* Department of City \& Regional Planning, Mehran University of Engineering \& Technology, Jamshoro.

** Department of Civil Engineering, Mehran University of Engineering \& Technology, Jamshoro.

This is an open access article published by Mehran University Research Journal of Engineering and Technology, Jamshoro under the CC by 4.0 International License. 
planned growth within destitute sub-regions and support socio-economic sectors, by improving accessibility standards and reducing travel time, both for freight and passenger transportation purposes.

Regional Transportation Planning is one of the disciplines, which tremendously took men to the modern era and assist in travelling thousands of miles efficiently and comfortably. Transportation planning is a crucial component for the economic development of aloof subregions [5]. In remote environments, it is the only hope, which gives access to economic opportunities and makes rural economies stable [6]. The explanation of the regional transportation planning scenario can be viewed in Fig. 1 .

It is palpable from Fig. 1 that the village population uses minor unpaved tracks to access nearby surroundings for the purpose of firewood, drinking water needs and agriculture. The same village when connect to the neighboring town uses minor paved roads for the purpose
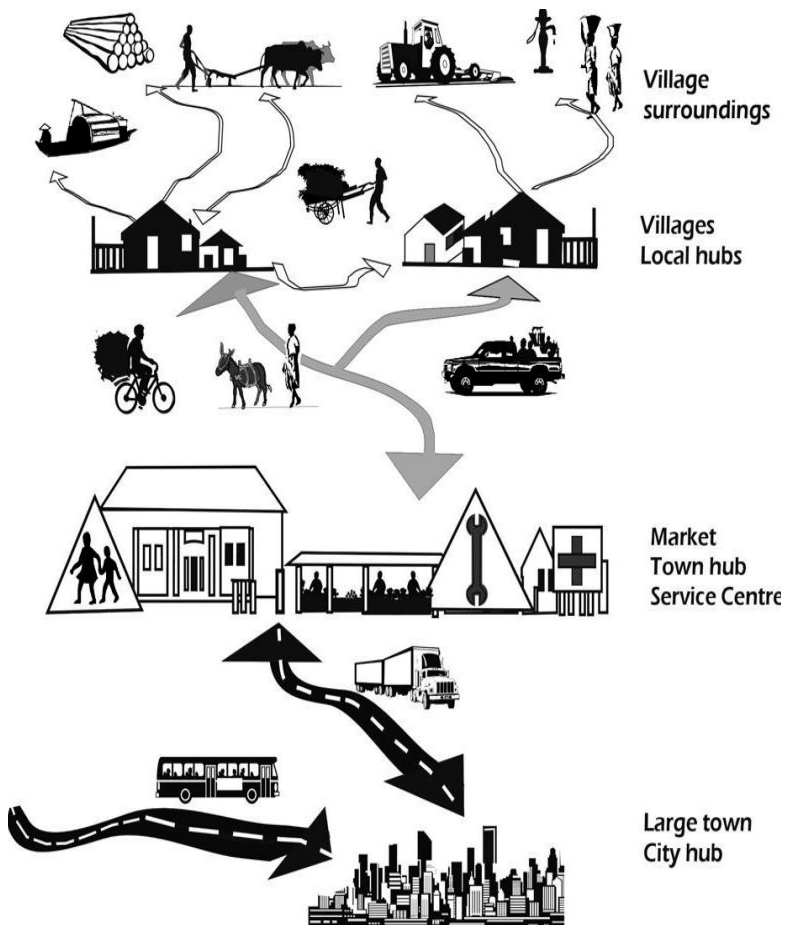

FIG. 1. RURAL-REGIONAL TRANSPORTATION SYSTEM [7] of health, education, service center and market accessibility. The town is connected with the city by arterial road or primary road, and having heavy traffic, like trucks and buses, etc.

The transportation sector can truly assist rural subregions from many aspects, like accessing basic services, completing daily activities, and travelling efficiently. It is proven that efficient completion of household activities put positive impacts on sub-regional socioeconomic structure and economy. Easy and efficient completion of daily routine activities of rural households is possible with the provision of apt land use standards and transportation services. For example, Fox [8] conceptualized human activities, which are efficiently served by regional transportation planning. These different activities can be shown in Fig. 2.

Fig. 2 demonstrates transportation activities of rural households. The improved regional transportation system provides a husband liberty to enjoy easy access to his workplace. After finishing his work, he can walk for sports activities, which are easily accessible to him. His son drives his car to school that picks his father for a home from the sports complex after fishing school. Now, wife can use the same car for shopping and can meet with friends without any hindrances. The grandmother can do some hangouts nearby open spaces with her pet. In this way, the overall household activities furnished efficiently without any problems and delays. Therefore, it seems positive to have regional transportation guidelines, which could assist in accomplishing household activities and valuate the scope of the regional transportation system. In order to provide transportation solutions and wayouts, this review study was conducted to propose policy guidelines and highlight the importance of transportation studies in the development of rural sub-regions of developing countries. 
The development of rural sub-regions can not only be accomplished by inducing the transport sector alone; one other important sector is vital in this regards, i.e. agriculture. It is really significant to promote the agriculture sector, by promoting rural-urban transport linkages and enhancing transport flows, as peasants can reach urban markets timely to earn valuable profits of their agricultural products. Thus, to strengthen the rural economy, it is expedient to promote the agriculture sector, which is the backbone of the rural-regional economy. Agriculture is a dominant sector, on which most of the rural economy depends, but due to unavailability of transport services, this sector is also tumbling in most of the rural sub-regions of developing countries.

\section{REMOTE REGIONS AND AGRICULTURE}

At segregated areas, ranchers without market data, and attempted to address with the issues of the purchasers from sustenance security and quality points of view. Accordingly, they are not having the capacity to give institutionalized farming items on a persistent premise [9]. It is to a great extent perceived that separated sub- locales regularly experienced higher expenses of the items than the market. The cost of transportation administrations assumes a grave part in clearing up the relationship amongst openness and horticultural advancement. Costs reflected and identified with the help of purchase inputs or item showcases, the greater part of the circumstances approximated, similar to its nearness to the road density [9-11].

In an article "Agricultural Marketing and Access to Transport Services," Hine and Ellis [12] illuminated that many developing nations anguished from monopolistic, low-volume high cost transportation and advertising frameworks. On the off chance that vehicle administrations are uneven of hopeless class or exorbitant, at that point workers would be in basic conditions and defenseless against monetary misfortunes, when they would endeavor to exchange their agrarian items. Similarly, costly transportation administrations will actually prompt low-cultivate entryway costs (the net value, the agriculturist gets from offering his product). Occasionally closed roads and irregular transportation offices, combined with lacking of storerooms for horticultural items can prompt misfortunes, as a few harvests (e.g. Wheat,

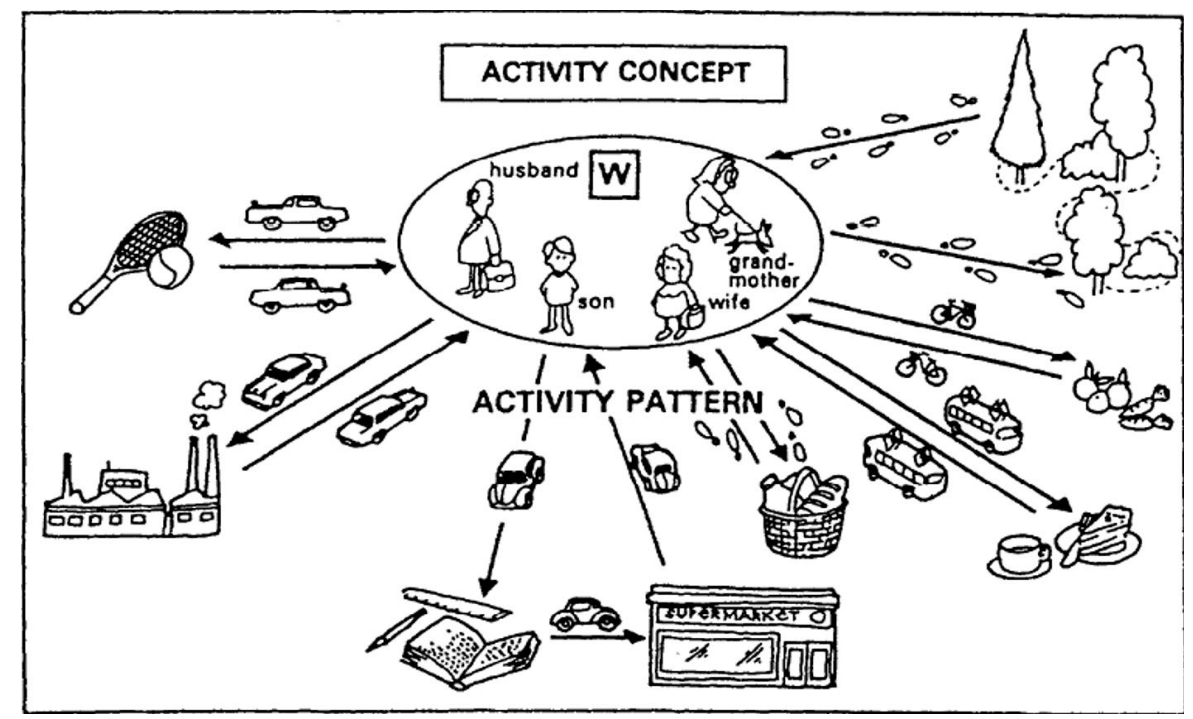

FIG. 2. TRANSPORT PLANNING AND HUMAN ACTIVITIES [8]

Mehran University Research Journal of Engineering \& Technology, Volume 37, No. 3, July, 2018 [p-ISSN: 0254-7821, e-ISSN: 2413-7219] 
Cotton, Rice and Sugarcane) deteriorate quickly with the progression of time. On the off chance that an excursion to the market is made over uneven streets, at that point organic products (e.g. Bananas, Mangoes and Oranges, and so forth) may likewise experience the ill effects of wounding, which would be brought about budgetary damages to the producers. IMT (Intermediate Means of Transport) can be advantageous option in such circumstances, since it is invaluable in dropping-down the transportation cost and time. The consequences for the agrarian generation can be complex:

(i) Cultivation on vast territories

(ii) Production of money products

(iii) Increased utilization of composts

(iv) Reduction of transport time, halfway utilized for the money era

Spillover impacts, if creatures are utilized for transport.

Along these lines, keeping in mind the end goal to handle such predicament arranging strategies are required, which can counter such rustic local issues. Provincial transportation approach arrangements are profitable in dealing with the present issues of availability at rustic areas and give facilitate proposals to consistent development. Local advancement specialists are in charge of making strategy arrangements for arranged improvement. The concerned specialists of rustic locales of the creating scene dependably attempted to address with the issues of normal men because of numerous hindrances. Therefore, the concerned experts neglected to dispatch arrangement recommendations so as to determine the vehicle related issues. Because of this, fundamental bottlenecks not cured in time and more regrettable with the progression of time.

\section{LITERATURE REVIEW}

Regional transportation planning is provided for the smooth transportation system of the entire region, which not only handled urban, but rural areas as well. However, due to some political influences and other inevitable reasons, the emphasis was always put on the urban area's planning in developing countries. Whereas, rural regions get problematic day by day due to negligence with respect to the availability of development funds and policy plans [13]. As a result, rural regions get "depressed" with improper road network hierarchy [14], unavailability of the public transportation system including rural roads [15], no employment opportunities [16], lack of basic health and education services[17-19], no land-use zoning regulations [20], the shortage of recreational spaces [21], unavailability of markets [22], no commercial centers and migrating people towards the developed regions in search of a better life [23,24].

Prior to the decade of ' $80 \mathrm{~s}$, preliminary approaches were mainly targeted transportation networks (e.g. provision of road facilities for motorized transport), and it was assumed that motorized transport is capable of solving the transport-related issues of rural households living in backward regions. After the decade of ' 80 s, transportation emerged as a supporting tool to enhance accessibility by encouraging rural-urban linkages and flows, which are essential especially for the socio-economic welfare of deprived regions and rural communities [25]. This changed scenario has developed many concerns about the rural regional transportation system in developing countries, which failed in producing the expected development outcomes in rural regions. It was observed that the most important part of the rural-regional voyage, i.e. off road network could not be undertaken using road and car approach [26]. 
The availability of transportation facilities and infrastructure are pretty much essential to renovate backward rural communities $[27,28]$. It is also understandable that alone availability of proper transport facilities could not bring prosperity within deprived rural environments. Hereafter, many other related sectors have to play their role in the sustainable socioeconomic development of remote sub-regions [29]. The ruralregional transport involves movement of people and goods to their relevant destinations. An efficient transportation system of any area has the mixture of small and large vehicles, which are being used for the public and personal uses.

IMT can be regarded as a useful travel and transport option for rural areas [30]. IMT is an essential transportation mode, which can be provided for the basic accessibility to the rural inhabitants. IMT comprised of bicycles, rickshaws, wheelbarrows, animal-driven vehicles (carts and wagons), motorcycles, motorized threewheelers and two-wheel tractors [31]. This mode can augment inter and intra sub-regional traffic flows between urban and rural areas, together with the increase in transportation demand. As demand for transport increases larger traffic flow expected between urban and rural areas and within the regions [32]. Mostly, higher traffic demand can be viewed at terminals, markets, and different stations, etc. A viewpoint of transportation planning has been transformed over the years. This changing scenario gradually based on the needs of the retrograde societies and households in deprived rural regions [33]. As shown in Table 1, researchers developed various transport-related tools or models, which can be used for the development of regressive communities. From the models as mentioned in Table 1; Gravity Model, Trip Generation Model, Travel Demand Model, Alonso Model and Trade Model are extensively utilized for the development of regressive communities.
The models as mentioned in Table 1, can be useful to implement various transport-related projects or studies to mitigate the problems of rural inhabitants. In addition to these models, need-based approach, on the other hand can provide credible solutions to the problems of deprived regions. The need-based approach can be implemented in a systematic process by taking assistance from the transportation planning process. The transportation planning process provided the orderly procedure to resolve the different issues related to the execution of rural transport projects.

\section{REGIONAL TRANSPORTATION PLANNING PROCESS}

The transportation planning process is an ordered procedure of managing different regional transportation planning activities, like health, education, shopping, work, employment and recreation. The stages as used in the transportation planning process can be utilized for the efficient completion of transportation projects [41]. The different steps and stages of the regional transportation planning process can be shown in Fig. 3. The numbers are added against each stage, which further clarify the flow of stages involved in the process.

The hierarchal steps as shown in Fig. 3 represent an ideal situation to tackle ever-increasing problems of rural regions. It is not always feasible to go through all these steps because of the constraints and local conditions, but whenever possible, it is worth considering all these steps of the regional transportation planning process in transportation planning research studies and development of rearward sub-regions. The stages as mentioned in Fig. 3, can also assist related transport authorities and transport planners to comply with the emerging transport-related issues of rural sub-regions.

Mehran University Research Journal of Engineering \& Technology, Volume 37, No. 3, July, 2018 [p-ISSN: 0254-7821, e-ISSN: 2413-7219] 


\section{REGIONAL TRANSPORTATION AUTHORITIES AND TRANSPORT PLANNERS}

Regional transportation authorities are developed to look after the regional land-use zoning, transportation related problems, environmental conditions and overall planning and development matters with their jurisdiction. These authorities are responsible for making the plans and devise them accordingly for urban as well as rural regional areas. Concerned authorities prepare the plans, targeting traffic congestion problems mostly in urban

TABLE 1. REGIONAL TRANSPORT MODELS

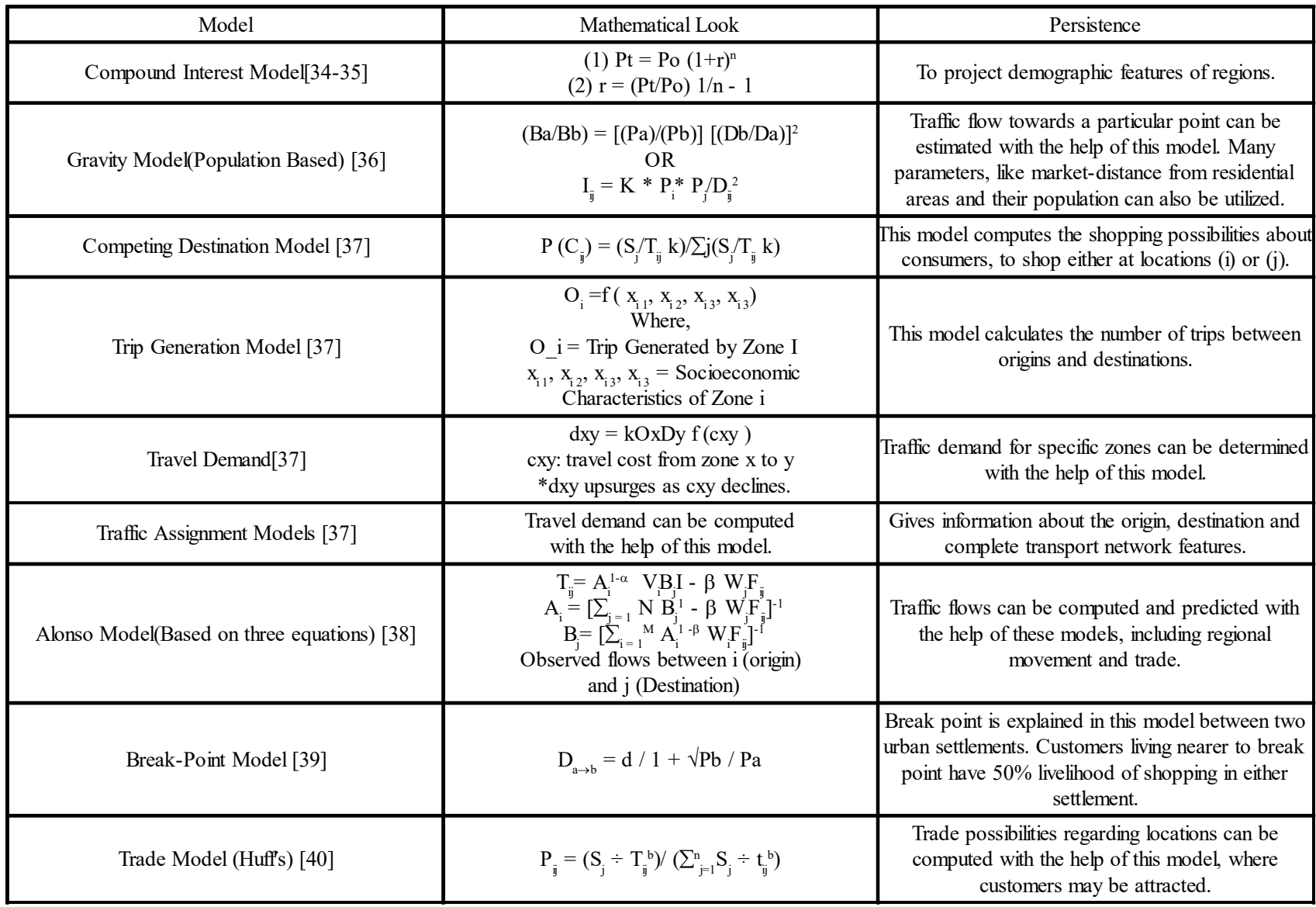

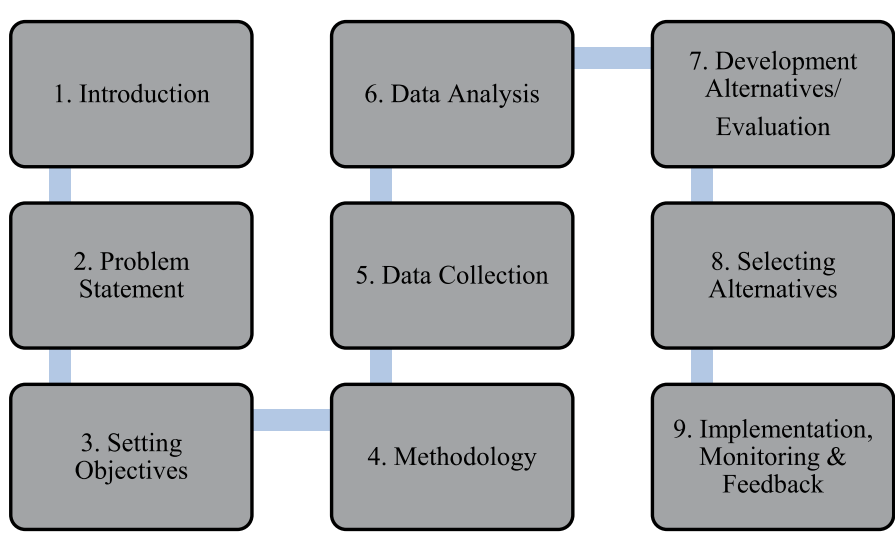

FIG. 3. REGIONAL TRANSPORTATION PLANNING PROCESS 
areas and solve the problems of transportation unavailability in rural regions. The handy tools, which are used mostly by the authorities to solve the transport sector and related problems are plans and policies, which are actually prepared with the help of experts, like Planners, Engineers and Architects.

Most of the concerned regional transportation authorities are carrying out the responsibilities of planning and development works. These authorities formulate policy plans for planning, designing, managing, reviewing and balancing the needs of the community by keeping in view the physical, socioeconomic and environment criteria. The transport policies in rural regions focus the individual accessibility issues with respect to basic facilities and amenities, like health, education, employment, work, recreation and markets.

Mostly transport planners are assigned jobs of making or formulating regional transportation policy plans with the help of other professionals, like Civil Engineers, Architects or Surveyors.

With reference to society of transport planners [42], the duties/jobs of regional transport planners are listed as follows:

(i) Give economic, social, and environmental consideration of their job

(ii) Understanding about planning standards and provide a framework for the future

(iii) Formulate regional transport policies that can assist in planning, and development of physical, socioeconomic and environmental sectors of the concerned rural region

(iv) Planning and designing of regional transport projects and services (v) Knowledge about the implementation tools of the concerned projects

(vi) Pleader of the community and expert in communication skills, planning and management.

Regional transportation plans are prepared to remedy the existing transport-related problems, and to provide the framework for smooth future development. The concerned transportation authorities prepared regional transport plans, which focus the problems of the rural population with respect to accessibility, and the availability of transport services in developing countries [43].

\section{TRANSPORTATION POLICY PLANS AND RURAL ACCESSIBILITY}

The development of transport-related policies and models [44] required data about household characteristics, travel patterns, land uses and socioeconomic features of the rural-regional population [45]. The decisions can be devised and executed with the help of transportation policy plans. Such plans, when implemented can eradicate the problems of rural households with respect to the availabilities of transportation services and facilities.

Accessibility and mobility factors of transportation planning can greatly influence socio economic well-being of the rural population [46]. In the past, transport-related services were analyzed with reference to the mobility criterion (physical movement). Later on, accessibility parameter was considered, i.e. "the ability of people who are interested in accessing goods, services, opportunities and employment, etc.”

Accessibility can be measured with the help of two wellknown components, i.e. transportation and activity $[47,48]$. 
(1) The activity component is a measure of land use classification in any region, which is shown by different destinations (opportunities). These destinations can be employment, education, health institutions or commercial areas. These destinations or opportunities can be given weights in order to calculate the attractiveness of flow of traffic. Shortages of these facilities according to the number of inhabitants can create accessibility problems, especially at deprived scattered locations.

(2) The transportation component can be used to measure transportation system, like travel time, travel cost, household size, household income and personal vehicle ownership. These are also called impedance factors, which negatively impact the different journeys and often concluded in their cancellation.

The other components of accessibility measure are temporal (time) and individual components [49]. A temporal component can be calculated within the limits of predefined time or in any particular time of the day. The overall accessibility measure is developed with respect to transportation and activity components.

The wider range of rural-regional socioeconomic problems, including higher mortality rates, illiteracy poverty, dilapidated trade and agriculture infrastructure erupted because of the absence of transport-related facilities and infrastructure [50-53]. Accessibility and landuse can be considered as important tools for the revitalization of urban and backward regions [54-59]. Transportation accessibility helps rural people in accessing their opportunities efficiently in time. Through the provision of low-cost transportation facilities and proper road connectivity, the rural population becomes more accessible and more prosper. The rural population can access their basic needs and complete their activities in time, which can put positive effects on the whole socioeconomic structure of destitute sub-regions $[60,61]$.

\section{CONTRIBUTION AND RESEARCH GAPS}

This review study contributed the existing knowledge and answered the following research questions:

(i) How transport planners can be beneficial in the development process of depressed sub-regions?

(ii) How transportation planning can flourish the rural regions and abridge gaps regarding their socioeconomic growth?

In addition, this study also clarifies that how transport decision-makers can execute policy proposals and different models to mitigate the transport-related bottlenecks of rural inhabitants. With the help credential transport availabilities, the interaction between destitute sub-regions and urban settlements in the developing counties can be consolidated, which seem inevitable for the growth of socioeconomic sectors. The accessibility issues can be reduced and transport flows can be enhanced in this way, which can improve the living standards of rearward societies. This study can help transport planners and development authorities to plan for the better accessible future, where different rural activities could be accomplished efficiently. The urbanization process can be curtailed in this way, which can balance the availability of resources equally for urban as well as rural settlements.

To propel the socio-economic development in depressed sub-regions, this study recommends the policy proposals, which can be reviewed hereafter. The policy guidelines emphasize on the accessibility standards of rural households.

Mehran University Research Journal of Engineering \& Technology, Volume 37, No. 3, July, 2018 [p-ISSN: 0254-7821, e-ISSN: 2413-7219] 


\section{PROPOSED POLICY IMPLICATIONS}

Rural households visit many destinations daily or weekly as needed (e.g. work sites, local markets, and health or education facilities). In a rural environment, these facilities should be evenly placed alongside the roads with rural settlements at one end as shown in Fig. 4. Sparsely located activities required more travel to reach them. If the destinations are located in close proximity, these could reduce the average travel time and distance, and even reachable by walk. Therefore, increase in a number of local markets, employment opportunities, and health or education facilities, according to standards tends to improve the accessibility. At the same time, short distances can increase the travel options available to the rural population, particularly walking.

Litman [62] proposed that accessibility standards could be increased, if facilities located close together as shown in Fig 4.

In Fig. 4, destinations are located close together along a roadway, which could increase accessibility. If destinations are close enough together, these can be easily reached by walking, which is suitable for rural sub-regions, where most of the people do not have their personal vehicles. In the same way, the center of a road link can reduce the average distance to each destination, which ultimately increases the accessibility as shown in Fig. 5.

A more central location reduces travel requirements, which can increase accessibility. Rural settlements with proper road connectivity can improve the accessibility standards of their residents. Every rural settlement has the road facilities, which provide basic access for the completion of routine activities. If markets, commercial centers, employment locations, health and education facilities would be provided along both the ends of the rural settlements as shown in Fig. 5, it could enhance the accessibility and improve the transportation flows. It is foreseen that accessibility standards can be increased in this way, which could inject socioeconomic development within deprived rural subregions.

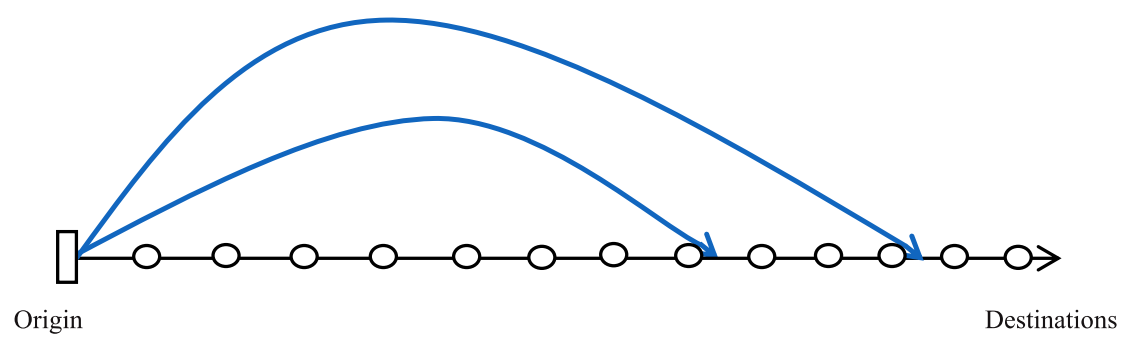

FIG. 4. ACCESSIBILITY FROM A LOCATION AT ONE END OF A ROADWAY

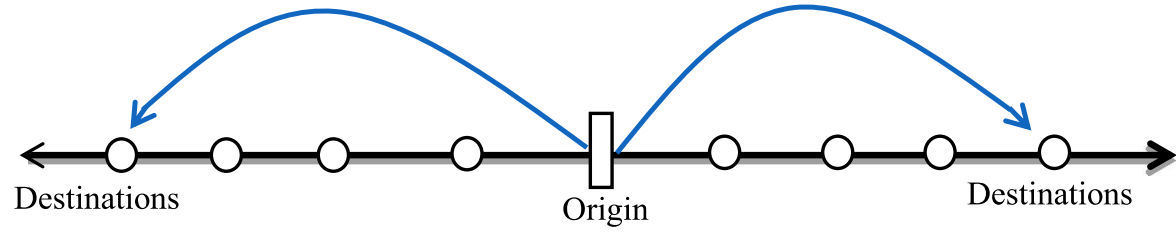

FIG. 5. ACCESSIBILITY FROM A LOCATION IN THE CENTER OF A ROADWAY

Mehran University Research Journal of Engineering \& Technology, Volume 37, No. 3, July, 2018 [p-ISSN: 0254-7821, e-ISSN: 2413-7219] 


\section{CONCLUSION}

Regional transportation planning is a key determinant in the development of rural regions of the developing world. The transportation sector provides connectivity to rural inhabitants, as they can serve their lives in a better way. Rural inhabitants need transportation services and facilities to fulfill their daily needs, including access to market, health, education, commercial centers and regional prominent settlements. The aim of writing this review article was to propose policy guidelines, focusing accessibility-related issues of rural households, living in depressed sub-regions of developing countries. Further, this study was also articulated to seek and deliver knowledge about the rural transport sector and its importance with respect to the planned development of rural sub-regions. This study is a part of the literature review conducted to provide transportation policy solutions to the destitute sub-regions of the developing countries. This review paper can provide a bunch of information to the readers about the regional transportation problems in the deprived rural regions. At the same time, this study unleashes the ideas that how transportation problems of the rural dwellers can be mitigated efficiently, which is almost seventy percent of the total population of developing countries. Moreover, to fulfil the aim of this study, and to eliminate the transportrelated problems of rural households, policy proposals were suggested to improve the accessibility criterion of the rural population. This should also be noted that suggestions or policy plans should be revised time to time, to answer the emerging issues of rural inhabitants.

\section{ACKNOWLEDGEMENTS}

The authors are thankful to reviewers for their valuable comments, which increased the quality of this review article. The authors are also grateful to Faculty Members, Department of City \& Regional Planning, Mehran University of Engineering \& Technology, Jamshoro, Pakistan, for their support.

\section{REFERENCES}

[1] Talpur, M.A.H., Napiah, M., Chandio, I.A., Qureshi, T.A., and Khahro, S.H., "Development of a Regional Transport Policy Support System for Rural Planning Agencies in Developing World", Procedia Engineering, Volume 77, pp. 2-10, 2014.

[2] Cheng, G., Zeng, X., Duan, L., Lu, X., Sun, H., and Jiang, T., "Spatial Difference Analysis for Accessibility to High Level Hospitals Based on Travel Time in Shenzhen, China", Habitat International, Volume 53, pp. 485-494, 2016 .

[3] Abbott, J., "Planning as Managing Uncertainty: Making the 1996 Livable Region Strategic Plan for Greater Vancouver", Planning Practice \& Research, Volume 27, pp. 571-593, 2012.

[4] Glasson, J., and Marshall, T., "Regional Planning", Routledge 2 Park Square, Milton Park, Abingdon, Oxfordshire OX14 4RN, Simultaneously Published in USA and Canada by Routledge 270 Madison Avenue, New York, NY 10016, 2007.

[5] Álvarez-Herranz, A., and Martínez-Ruiz, M.P., "Evaluating the Economic and Regional Impact on National Transport and Infrastructure Policies with Accessibility Variables", Transport, Volume 27, pp. 414-427, 2012.

[6] Quinet, E., and Vickerman, R.W., "Principles of Transport Economics", Edward Elgar, Cheltenham, pp. 416, 2004.

[7] Starkey, P., Ellis, S., Hine, J., and Ternell, A., "Improving Rural Mobility: Options for Developing Motorised and Non-Motorised Transport in Rural Areas", Technical Paper, The World Bank, Washington DC, USA, 2002.

[8] Fox, M., "Transport Planning and the Human Activity Approach", Journal of Transport Geography, Volume 3, pp. 105-116, 1995.

[9] Pfaff, A., Robalino, J., Walker, R., Aldrich, S., Caldas, M., and Reis, E.,"Road Investments, Spatial Spillovers, and Deforestation in the Brazilian Amazon", Journal of Regional Science, Volume 47, No. 1, pp. 109-123, 2007.

[10] Pfaff, A., "What Drives Deforestation in the Brazilian Amazon?," MIT Joint Program on the Science and Policy of Global Change Postal Address: 77 Massachusetts Avenue MIT E40-271 Cambridge, MA 02139-4307, USA, 1996.

[11] Chomitz, K., and Thomas, T., "Determinants of Land use in Amazonia: AFine-Scale Spatial Analysis", Journal of Agricultural Economics, Volume 85 4, pp. 1016-1028, 2003. 
[12] Hine, J.L., and Ellis, S.D., "Agriculture Marketing and Access to Transportation Service",Rural Transport Knowledge Base -1, Rural Travel and Transport Program, Volume 4, No.3, pp. 1-11, 2001.

[13] Ahern, A., and Hine, J., "Rural Transport - Valuing the Mobility of Older People", Research in Transportation Economics, Volume 34, pp. 27-34, 2012.

[14] Barrios, E.B., "Infrastructure and Rural Development: Household Perceptions on Rural Development", Progress in Planning, Volume 70, pp. 1-44, 2008.

[15] Bryceson, D.F., Bradbury, A., and Bradbury, T., "Roads to Poverty Reduction? Exploring Rural Roads' Impact on Mobility in Africa and Asia", Development Policy Review, Volume 26 4, pp. 459-482, 2008.

[16] Arif, G.M., Nazli, H., and Haq, R., "Rural Non-Agriculture Employment and Poverty in Pakistan", The Pakistan Development Review, Volume 39, pp. 1089-1110, 2000.

[17] Arcury, T.A., Preisser, J.S., Gesler, W.M., and Powers, J.M., "Access to Transportation and Health Care Utilization in a Rural Region", The Journal of Rural Health, Volume 21, pp. 31-38, 2005.

[18] Brown, P.H., and Park, A., "Education and Poverty in Rural China", Economics of Education Review, Volume 21, pp. 523-541, 2002.

[19] Bell, S., Wilson, K., Bissonnette, L., and Shah, T., "Access to Primary Health Care: Does Neighborhood of Residence Matter?", Annals of the Association of American Geographers, Volume 103, pp. 85-105, 2012.

[20] Aytur, S.A., Rodriguez, D.A., Evenson, K.R., Catellier, D.J., and Rosamond, W.D., "The Sociodemographics of Land-Use Planning: Relationships to Physical Activity, Accessibility, and Equity", Health \& Amp; Place, Volume 14, pp. 367-385, 2008.

[21] Wright-Wendel, H.E., Zarger, R.K., and Mihelcic, J.R., "Accessibility and Usability: Green Space Preferences, Perceptions, and Barriers in a Rapidly Urbanizing City in Latin America", Landscape and Urban Planning, Volume 107, pp. 272-282, 2012.

[22] Reggiani, A., Bucci, P., Russo, G., Haas, A., and Nijkamp, P., "Regional Labour Markets and Job Accessibility in City Network Systems in Germany", Journal of Transport Geography, Volume 19, pp. 528-536, 2011.

[23] Firdaus, G., and Ahmad, A., "Impact Analysis of Urbanization on Rural Livelihood - An Empirical Study of an Urban Centre of Delhi, India”, International Journal of Urban Sciences, Volume 15, pp. 147-160, 2011.
[24]

$[25]$

\section{$[26]$}

[29] Weneger, M., and Bokemann, D., "The SASI Model: Model Structure. Socio-Economic \& Spatial Impacts of European Transport Networks", Institute for Raumplanung, University Dortmund, Germany, 1998.

[30] Calvo, C.M., "Case Study on Intermediate Means of Transport Bicycles and Rural Women in Uganda", The World Bank and Economic Commission for Africa SSATP. Working Paper No. 12, 1994.

[31] Anchirinah, V.M., Addison, M., Dapaah, H.K., and Yiridoe, E.K., "Prospects of Using Improved Intermediate Means of Transport in Ghanaian Agriculture: A Survey", Journal of Sustainable Agriculture, Volume 17, pp. 145-168, 2001.

[32] Cullinane, S.L., Cullinane, K.P.B., Fewings, J., and Southwell, J., "Rural Traffic Management: The Burrator Reservoir Experiment", Transport Policy, Volume 3, pp. 213-224, 1996.

[33] Howe, J., "The Impact of Rural Roads on Poverty Alleviation: A Review of the Literature", International Labour Office, Income Distribution and Employment Programme, Working Paper No. 106, 1981.

[34] Mehta, A.C., "Demographic-Economic Interaction Model for Sub-national Population Projections - A Case Study of Rajasthan”, Rajasthan Economic Journal, Volume 17, Jaipur, India, 1996.

[35] Roberts, M., "An Introduction to Town Planning Techniques", Hutchinson Educational, 1974.

[36] Anderson, S.J., Volker, J.X., and Phillips, M.D., "Converse's Breaking-Point Model Revised", Journal of Management and Marketing Research, Volume 3, 2010. 
[37] Nagurney, A., "Models of Transportation and Networks (Refereed Encyclopedia Article)", Mathematical Models in Economics, Encyclopedia of Life Support Systems, Zhang, W.-B., (Editor), UNESCO., 2007.

[38] Nijkamp, P., and Poot, J., "Mathematical Models in Economics", Mathematical Models in Regional Economics, Encyclopedia of Life Support System, Volume 2, 2011.

[39] Ghosh, A., and Mclafferty, S., "Sale Forecasting and Store Assessment Methods, Location Strategies for Retail \& Service Firms", Lexington Books, pp. 61-125, 1987.

[40] Timmermans, H.J.P., "Multi Attribute Shopping Models and Ridge Regression Analysis", Environment and Planning Volume 13, 1981.

[41] Administration, F.H., "The Transportation Planning Process: Key Issues: A Briefing Book for Transportation Decision Makers, Officials, and Staff: A Publication of the Transportation Planning Capacity Building Program", Federal Highway Administration, Federal Transit Administration, US Department of Transportation, 2007.

[42] Society, T.P., "Draft National Occupational Standards for Transport Planning",http://www.ciht.org.uk/ and http://tps.org.uk, 2006. Retrieved on $25^{\text {th }}$ March, 2015.

[43] Talen, E., "After the Plans: Methods to Evaluate the Implementation Success of Plans", Journal of Planning Education and Research, Volume 16, pp. 79-91, December 1, 1996.

[44] Sanchez, T.W., "Poverty, Policy, and Public Transportation", Transportation Research Part-A", Policy and Practice, Volume 42, pp. 833-841, 2008.

[45] Kitamura, R., Fujii, S., and Pas, E. I., "Time-Use Data, Analysis and Modeling: Toward the Next Generation of Transportation Planning Methodologies", Transport Policy, Volume 4, pp. 225-235, 1997.

[46] Preston, J., and Raje, F., "Accessibility, Mobility and Transport-Related Social Exclusion", Journal of Transport Geography, Volume 15, pp. 151-160, 2007.

[47] Handy, S.L., and Niemeier, D.A., "Measuring Accessibility: An Exploration of Issues and Alternatives", Environment and Planning-A, Volume 29, pp. $1175-1194,1997$.

[48] Koenig, J.G., "Indicators of Urban Accessibility: Theory and Application", Transportation, Volume 9, pp. $145-172,1980$.

[49] Geurs, K., and Ritsema, V.E., "Accessibility Measures: Review and Applications: Evaluation of Accessibility Impacts of Land-Use Transportation Scenarios, and Related Social and Economic Impact", National Institute of Public Health and the Environment, 2001.

[50] Kam, S.P., Hossain, M., Bose, M.L., and Villano, L.S., "Spatial Patterns of Rural Poverty and Their Relationship with Welfare-Influencing Factors in Bangladesh", Food Policy, Volume 30, pp. 551-567, 2005.
Nanayakkara, A.G.W., "Poverty in Sri Lanka - Issues and Options", Department of Census and Statistics, pp. 1-46, Sri Lanka,2006.

[52] Olsson, J., "Responses to Change in Accessibility: SocioEconomic Impacts of Road Investment: The Distributive Outcomes in Two Rural Peripheral Philippine Municipalities", Ph.D. Thesis, Department of Human and Economic Geography, University of Gothenburg, Goteborgs, 2007.

[53] Guagliardo, M.F., "Spatial Accessibility of Primary Care: Concepts, Methods and Challenges", International Journal of Health Geographics, Volume 3, pp. 1-13, 2004.

[54] Laurance, W.F., Albernaz, A.K.M., Schroth, G., Fearnside, P.M., Bergen, S., Venticinque, E.M. and Da-Costa, C., "Predictors of Deforestation in the Brazilian Amazon", Journal of Biogeography, Volume 29, pp. 737-748, 2002.

[55] Nagendra, H., Southworth, J., and Tucker, C., "Accessibility as a Determinant of Landscape Transformation in Western Honduras: Linking Pattern and Process", Landscape Ecology, Volume 18, pp. 141-158, 2003.

[56] Verburg, P.H., Overmars, K.P., and Witte, N., "Accessibility and Land-Use Patterns at the Forest Fringe in the Northeastern Part of the Philippines", Geographical Journal, Volume 170, pp. 238-255, 2004.

[57] Castella, J.C., Manh, P.H., Kam, S.P., Villano, L., and Tronche, N.R., "Analysis of Village Accessibility and Its Impact on Land-Use Dynamics in a Mountainous Province of Northern Vietnam", Applied Geography, Volume 25, pp. 308-326, 2005.

[58] Etter, A., McAlpine, C., Wilson, K., Phinn, S., and Possingham, H., "Regional Patterns of Agricultural LandUse and Deforestation in Colombia", Agriculture, Ecosystems \& Amp; Environment, Volume 114, pp. 369-386, 2006.

[59] Hanson, S., "Dimensions of the Urban Transportation Problem", Geographic Perspectives on Urban Transportation, pp. 3-23, 1986.

[60] Talpur, M.A.H., Napiah, M., Chandio, I.A., and Memon, I.A., "Analyzing Public Sector Education Facilities: A Step Further Towards Accessible Basic Education Institutions in Destitute Subregions", International Education Studies, Volume 7, pp. 110-119, 2014.

[61] Talpur, M.A.H., Napiah, M., Chandio, I.A., and Qureshi, T.A., "An Analysis of Umer Kots' Public Sector Education Facilities: A Deserted Subregion in Southern Pakistan", Research Journal of Applied Sciences, Engineering and Technology, Volume 7, pp. 1856-1862, 2014.

[62] Litman, T., "Evaluating Accessibility for Transportation Planning: Measuring People's Ability To Reach Desired Goods and Activities", Victoria Transport Policy Institute, 2011. 